\begin{tabular}{l|c|c|}
\hline DE & DE GRUYTER \\
\hline $\mathrm{G}$ & EPEN & DOI 10.1515/ethemes-2016-0014 \\
\hline
\end{tabular}

\title{
IMPACT OF NATIONAL CULTURE ON INTERNATIONAL HUMAN RESOURCE MANAGEMENT
}

\author{
Biljana Đorđević \\ University of Niš, Faculty of Economics, Serbia \\ \biljana.djordjevic@eknfak.ni.ac.rs
}

UDC

005.96

Review

Abstract: In today's business conditions, the internationalisation of business becomes an almost inevitable precondition for future growth paper

Received: 22.09.2015.

Accepted:

23.03.2016. and development of organisations. However, internationalisation of business usually requires organisations to implement some changes in the way they operated in the previous period. One of the areas that require some changes is the area of human resource management, too. Factors which require modifications in this system are related primarily to the legal regulations of other countries, but also to the characteristics of their national culture. The former influence comes from the fact that national culture exerts a powerful influence on the system of values, attitudes and behaviour of people in a particular country and, among the other things, on the preferences for policies and procedures in the field of human resources management. Starting from the above, this paper analyses the impact of certain dimensions of national culture on the preferred content of human resources management in organisations in certain countries. The aim of the paper is to provide the theoretical basis for organisations that internationalised their business, or intend to do so, to create system of human resource management in the entities abroad which, at least, will represent the balance between the system that is applied at headquarter and one that is preferred in entities abroad, in order to be effective.

Keywords: internationalisation, national culture, international human resource, employees.

JEL classification: F23, F53

\section{Introduction}

In today's business environment characterised by the process of globalisation and extremely strong competition, a growing number of organisations a chance for further growth and development seek in the process of internationalisation of the business. However, entering at the international business scene carries a 
number of challenges. First of all, the expansion of business in other countries require possessing knowledge about their legal regulations, the characteristics of the local labour market, characteristics of the political and economic system, the characteristics of the national culture, etc. These are the reasons which require organisations that internationalize their business to implement certain modifications in their former way of doing business and, among other things, in the system of human resource management (HRM).

Since the national culture, as a system of deeply founded values, attitudes and behaviours of the members of a society (Leung et al., 2005) to a large extent determines the characteristics of other systems of the country (legal, political, economic and others), it implies that the culture of observed countries is one of the most important factors that must be taken into account in the case of entering at the international business scene. Consequently, the national culture becomes a very important factor when it comes to designing the content of international human resource management (IHRM), too. The fact that national culture is very important for the content of IHRM is clearly singled out by the fact that within this concept a special segment, comparative human resource management, which examines the differences in the content of HRM between countries primarily caused by the characteristics of the national culture, has emerged.

Having in mind the fact that national culture has influence on the preferred style and the content of HRM in organisations of a certain country (Stone et al., 2006), the aim of this paper is to show the connection between certain dimensions of national culture and preferred policies and procedures in this area. The initial assumption of the paper is that organisations when within the framework of the internationalisation of business establish business entities in other countries, should recognise the impact of national culture of the host country when designing the content of IHRM in order to be effective.

The paper is structured as follows: firstly, it reviews the literature about the concept of IHRM and the most known models of national culture formulated by the referent authors from this field, then analyses the impact of dimensions of the national culture on particular policies and procedures in the field of HRM, while the last part analyses the impact of national culture of some countries on the preferred content of HRM in them. In the paper the method of analysis, synthesis, comparison and generalisation were used.

\section{The Concept of International Human Resource Management}

As a result of business expansion beyond the borders of a country and the need to manage geographically dispersed workforce of diverse cultural background, 
within the field of human resources management intensively is developing a special segment - international human resources management (IHRM). This concept characterizes numerous specifics in comparison to the so-called national human resource management, particularly the need of organisations that have internationalized business while designing the policies and procedures from the area of human resource management to take into account the specificities of the local area. ${ }^{1}$

When we speak about what IHRM really means, the referent literature provides us many answers. For example, Briscoe and his associates (2009) under IHRM assume studying and implementing all activities from the field of HRM that have an impact on the process of human resources management in organisations in the global environment (Briscoe et al., 2009, p. 20). Scullion (2005), for example, believes that IHRM represents the way in which multinational companies (MNCs) manage their geographically dispersed workforce trying to gain competitive advantage in the local and global level through the human resources (Scullion, 2005, p. 5). Furthermore, Gomes (2012) believes that the IHRM is the process of acquiring, allocation and effective use of human resources in international business (Gomes, 2012, p. 2). Similar opinion has Taylor and his associates (1996), who point out that IHRM is a set of activities, functions and processes aimed at attracting, developing and retaining human resources in the MNCs, i.e. set of activities that are used to manage employees in MNCs both in the country and abroad (Teylor et al., 1996, p. 960).

From the above it can be concluded that in understanding the essence of the concept of IHRM there are no major differences. Also, it can be concluded that this area is of a great interest. Consequently, the literature from this field is very rich, and within this concept three specific areas can be clearly distinguished (Brewster et al., 2007):

- Cross-cultural management,

- Comparative human resource management and

- International human resource management.

Authors dealing with cross-cultural aspect of IHRM base their research on the fact that each country has its own unique set of deep-based values and beliefs that are reflected in the way the people in that country think and behave, and how that society functions in general. The authors that belong to this field believe that understanding these differences is crucial for organisations with internationalized business in order to adequately design the activities in the area

\footnotetext{
${ }^{1}$ The obligation for every company is to implement legislation rules that applies in the host country. However, the extent to which other specifics really will be taken into account will depend on the strategic approach of IHRM that MNC adopted. These approaches can be: ethnocentric, polycentric, regiocentric or geocentric approach.
} 
of IHRM, such as recruitment, selection, training and development, performance measurement, staff remuneration, etc.

Within the area of comparative human resource management two key areas of research could be identified. The first area is related to the differences in the content and preferred style of HRM between countries, while the second area of research is related to the study of differences in the content of HRM within one MNC which has its entities in different countries.

International human resource management, as the third area of study within the IHRM, deals with the way in which organisations that have internationalized their businesses manage human resources in entities abroad. The authors in this field focus on those parts of HRM which had to be modified due to entering companies at the international business scene.

The foregoing shows that in all segments of the concept of IHRM national culture has an important place and that the specifics of IHRM, comparing to the national HRM,are largely based precisely on the impact of the characteristics of this variable. Therefore, in the following text the national culture and its dimensions observed from the perspective of the referent authors from this field will be discussed.

\section{Dimensions of National Culture as a Basis for Designing International Human Resource Management}

About what is meant by national culture there are many answers. However, most authors when defining national culture as a category base their opinion on the definition formulated by Gerhart Hofstede. The aforementioned author believes that national culture is a kind of mental programming, or patterns of thought, feeling and action that each person acquires in childhood, and then applied throughout life (Hofstede, 2001, p. 25).

National culture is the category which is very much studied, among the other things because of the fact that it is a convenient tool for explaining many phenomena in management, such as leadership style, organisational structure, motivation, etc. (House et al., 2004; Hofstede, 2001). However, this concept has also been proven to be a suitable tool for clarifying the difference in preferred content of HRM between members of different countries.

The first authors who studied the national culture through certain dimensions were Kluckhohn and Strodtbeck (1961). These authors believe that the dimensions of national culture, in fact, reflect the fundamental issues that every society faces with (Kluckhohn \& Strodtbeck, 1961). They pointed out that on each fundamental question there are three possible answers, which reflect the differences in the characteristics of national cultures of different countries. The 
overview of fundamental questions, i.e. dimensions of national culture, as well as the possible answers to these questions according to Kluckhohn and Strodtbeck are given in Table 1.

Table 1 Dimensions of national culture according to Kluckhohn and Strodtbeck

\begin{tabular}{|l|l|}
\hline $\begin{array}{c}\text { The fundamental question / } \\
\text { dimensions of national culture }\end{array}$ & \multicolumn{1}{c|}{ Dominant belief } \\
\hline Understanding human nature & $\begin{array}{l}\text { People by nature are good. } \\
\text { People by nature are evil. } \\
\text { People by nature are neither good nor evil. }\end{array}$ \\
\hline The relationship with nature & $\begin{array}{l}\text { People can and should master nature. } \\
\text { People must subjugate nature. } \\
\text { People should achieve harmony with nature. }\end{array}$ \\
\hline The nature of human activity & $\begin{array}{l}\text { People should strive to achieve specific goals and } \\
\text { accomplishment. } \\
\text { People should strive do develop themselves into } \\
\text { integrated whole. } \\
\text { People should focus on living at the present moment. }\end{array}$ \\
\hline Relationship among individuals & $\begin{array}{l}\text { Individualistic - the advantage has own interests. } \\
\text { Collateral - primacy have small groups and care for } \\
\text { them. } \\
\text { Lineal - relations between people are based on the } \\
\text { relationships of dominance and subordination. }\end{array}$ \\
\hline Time orientation & $\begin{array}{l}\text { Past. } \\
\text { Present. } \\
\text { Future. }\end{array}$ \\
\hline Understanding the space & $\begin{array}{l}\text { Private. } \\
\text { Public. } \\
\text { Mixed. }\end{array}$ \\
\hline
\end{tabular}

Source:Kluckhohn, F. R. \&. Strodtbeck, F. L (1961).Variations in value orientations. Evanston: Row, Peterson. (Quoted in Hills, M. D. (2002). Kluckhohn and Strodtbeck's Values Orientation Theory.Online Readings in Psychology and Culture, 4(4).http://dx.doi.org/10.9707/2307-0919.1040).

One of the most famous models of national culture is the model formulated by Gerhart Hofstede (1980). The aforementioned author firstly found that there are four key dimensions according to which national cultures differ, and later added a fifth one (time orientation) (Hofstede, 1980; Hofstede \& Bond, 1984). Dimensions according to which national cultures differ aforementioned author found in the extensive study conducted while he was employed as a psychologistat IBM. This study included 117,000 employees of the company who were employed in more than 40 countries. Review of the national culture dimensions according to Hofstede is given in Table 2. 
Table 2 Dimensions of national culture according to Hofstede

\begin{tabular}{|l|l|l|}
\hline \multicolumn{1}{|c|}{$\begin{array}{c}\text { Dimension of national } \\
\text { culture }\end{array}$} & $\begin{array}{l}\text { Content } \\
\text { Power distance }\end{array}$ & $\begin{array}{l}\text { Low - power is dispersed in society and people see } \\
\text { themselves as equal. } \\
\text { High - society accepts (approve) the unequal distribution } \\
\text { of power. }\end{array}$ \\
\hline Uncertainty avoidance & $\bullet \begin{array}{l}\text { Low- people are tolerant of risk and different/alternative } \\
\text { options. } \\
\text { High - people feel fear and embarrassment when they find } \\
\text { themselves in unusual situations. }\end{array}$ \\
\hline Collectivism & $\bullet \begin{array}{l}\text { Individualism - connections between people are weak; it is } \\
\text { expected that everyone takes care of his/her own interests } \\
\text { and the interests of his/her immediate family. } \\
\text { Collectivism - people from the birth are integrated into } \\
\text { cohesive groups which provide lifelong protection in } \\
\text { exchange for loyalty. }\end{array}$ \\
\hline $\begin{array}{l}\text { Masculine vs. feminine } \\
\text { values }\end{array}$ & $\begin{array}{l}\text { Masculine values - there is a strong tendency for } \\
\text { achievements; awards and recognitions are the main } \\
\text { motivating factors of behaviour. }\end{array}$ \\
\hline $\begin{array}{l}\text { Feminine values - the emphasis is on the quality of life, } \\
\text { sustainable development of society, the balance between } \\
\text { private and professional life; there are no differences } \\
\text { between women and men in the same positions. }\end{array}$ \\
\hline $\begin{array}{l}\text { Long-term orientation - people values tradition, they are } \\
\text { patience and persistence to achieve results that will be } \\
\text { manifested in the long run. } \\
\text { Short-term orientation - focus is on the present and the } \\
\text { near future. }\end{array}$ \\
\hline
\end{tabular}

Source:adapted according to Hofstede, G. (1983). The cultural relativity of organizational practices and theories.Journal of International Business Studies, 14 (2),

75-89 i Hofstede, G. \& Bond, M. H. (1984). Hofstede's Culture Dimensions: An Independent Validation Using Rokeach's Value Survey.Journal of Cross-Cultural Psychology, 15 (4), 417-433.

Extensive research of the dimensions of national culture was also conducted by Fons Trompenaars and Hampden-Turner (1997). The study, which lasted over 10 years, and by which has been covered more than 1,500 executives from 28 countries, the aforementioned authors found that there are seven dimensions by which national cultures differ. These dimensions are as follows (Table 3).

Project GLOBE (Global Leadership and Organisational Behaviour Effectiveness) is also a very ambitious research project in the field of the study of culture, conducted in the 1990s of the 20th century. The goal was to determine whether and which dimensions of leadership are caused by the characteristics of the national culture. This project included over 17,000 middle managers from 62 countries. According to the researchers of the project 
GLOBE there are nine dimensions of national culture, such as: power distance, uncertainty avoidance, human orientation, institutional collectivism, intragroup collectivism, determination, gender equality, orientation towards the future, focus on performance (House et al., 2004).

Table 3 Dimensions of national culture by Trompenaars and Hampden-Turner

\begin{tabular}{|c|c|}
\hline $\begin{array}{r}\text { Dimensic } \\
\text { national c }\end{array}$ & Content \\
\hline $\begin{array}{l}\text { Universalism vs. } \\
\text { particularism }\end{array}$ & $\begin{array}{l}\text { - Universalism - there is a belief that certain principles and rules } \\
\text { are the best and should be applied in all situations or countries. } \\
\text { - Particularism - emphasizes the uniqueness and the need of } \\
\text { taking into account the specificities in all spheres of life. }\end{array}$ \\
\hline $\begin{array}{l}\text { Individualism vs. } \\
\text { communitarianism }\end{array}$ & $\begin{array}{l}\text { - Individualism - interests of the individual and his/her family are } \\
\text { above the group interests. } \\
\text { - } \quad \text { Communitarianism - interests of the group have priority. }\end{array}$ \\
\hline $\begin{array}{l}\text { Neutral vs. } \\
\text { emotional }\end{array}$ & $\begin{array}{l}\text { - Neutral-people try to control their emotions and to demonstrate } \\
\text { poise and composure. } \\
\text { Emotional - individuals are not reluctant to express their } \\
\text { deepest emotions. }\end{array}$ \\
\hline Specific vs. diffuse & $\begin{array}{l}\text { - Specific- people clearly separates public and private life and the } \\
\text { roles that have in their lives, where these roles do not influence } \\
\text { each other. } \\
\text { Diffuse - the difference between private and public life is not } \\
\text { clear; the roles of people, public and private, are not separated } \\
\text { and the individual is seen as an integral person. }\end{array}$ \\
\hline $\begin{array}{r}\text { Achiever } \\
\text { ascrip }\end{array}$ & $\begin{array}{l}\text { - Achievement - peoples worth is evaluated on the basis of } \\
\text { personal competences and outcomes that are the result of } \\
\text { individual work and achievements. } \\
\text { - Ascription- peoples are valued according to personal } \\
\text { relationships and family heritage. }\end{array}$ \\
\hline Time orientation & $\begin{array}{l}\text { - Sequential time culture -time is viewed as a resource so it tends } \\
\text { to be used in the most efficient way; there is no clear line } \\
\text { between the time dedicated to work and other activities. } \\
\text { - Synchronic time culture - there is a clear distance between work } \\
\text { and pleasure; relations between people are much more } \\
\text { important than strict adherence to the agenda, protocol, etc. }\end{array}$ \\
\hline $\begin{array}{l}\text { Internal direction } \\
\text { vs. outer direction }\end{array}$ & $\begin{array}{l}\text { - Internal directed culture- people believe that they can influence } \\
\text { and control their environment (and their destiny). } \\
\text { - Outer directed culture- people believe that they cannot } \\
\text { influence neither the environment nor on their own destiny. }\end{array}$ \\
\hline
\end{tabular}

Source: Trompenaars, F. \& Hampden-Turner, C. (1997). Riding the Waves of Culture:

Understanding Cultural Diversity in Business (2nd ed). London: Nicholas Brealey

Publishing. (quoted in Vance, M. Ch. \& Paik, Y. (2006). Managing a global workforce: challenges and opportunities in international human resource management. New York: M. E Sharpe, Inc.). 
It can be concluded that the researchers in this project have been adopted the dimensions of culture as they have been formulated by the previous authors. However, their contribution is reflected in the fact that they found that there are some dimensions of leadership that are important to its effectiveness in different cultures, i.e. there are dimensions of leadership that differently affect the effectiveness of leadership in different cultures (Janićijević, 2013, p. 584).

In addition, it is important for the design of policies and procedures within IHRM to know the dimensions of the national culture of a certain country, it is important to bear in mind the fact that the characteristics of the culture of a certain country are not static, but dynamic category which can change during the time. These changes can have two directions: (a) reducing the cultural differences between different countries, which is known as cultural convergence and (b) the deepening of differences, which is known as cultural divergence (Thomas, 2008).

A factor that specially contributed to the cultural convergence is the process of globalisation. However, besides the fact that globalisation significantly contributed to the cultural convergence there are many other factors which also contributed to cultural convergence, such as developing the mass media, migration of people in order to acquire education or for economic reasons, etc. These phenomena indicate that certain norms of behaviour, way of thinking and values combine with others, and as a result a mixture of different cultures appears. So, it happens that many traditional collectivist culture accept a certain individualistic norms of behaviour and, conversely, individualistic culture accept certain norms of behaviour from collectivist cultures.

In contrast to the cultural convergence there is an opposite phenomenon cultural divergence. This phenomenon implies that the cultures over time become more and more distanced and that their characteristics become more and more diverse (Vance \& Paik, 2006).

However, in the literature there is almost a consensus that cultural convergence and cultural divergence are extremes, i.e. that they are phenomenon which are located at the opposite sides of the continuum. In the reality what really happens is the process of crossvergence (Ralston et al., 1997). There is the expectation that this trend (crossvergence) will continue in the future and will be increasingly strengthened by the process of globalisation.

In order to investigate the influence of the culture of a specific country on the HRM system in organisations of that country and to analyse its implications for the content of IHRM, it is important to bear in mind that besides the dimensions of national culture of the country concerned, HRM system in organizations is also influenced by the organizational (corporate) culture. The question that naturally arises here is: What culture, national or organisational, has a greater influence on the attitudes and behaviour of the employees in a 
particular organization? Most of the authors believe that the greater influence on the behaviour and attitudes of employees in particular organisation, and also on the preferred content of HRM, has a national culture. As the argument for such an opinion, authors state that people establish their organisational values after their nationally based values have already been developed, and that they their existing system of values transfer to the organisation. On the other hand, if there are discrepancies between the values that promote national culture and the values that promote the founder of the organisation, authors believe that the impact of organisational culture on the employees 'values, fundamental attitudes and beliefs is weaker in comparison to the influence of the national culture. Authors also believe that the influence of organisational culture on the attitudes and behaviour of the employees is of a shorter duration (Triandis, 1995). This suggests that national culture has a strong influence on which policies and practices in the field of HRM in a particular country will be more preferred and generally more prevalent.

\section{Influence of Some Dimensions of National Culture on the Content of Human Resources Management}

The influence of national culture on the content of the HRM can be monitored and analysed in almost all its segments. However, the following text will analyse how certain dimensions of national culture exert their influence on key activities in this field, such as: recruitment and selection of candidates, training and development of the employees, performance appraisal and remuneration.

Regarding the influence of national culture on the recruitment of candidates this impact can be analysed how national culture affects this process through the system of values of the recruiters, but also through the system of values and preferences of the job applicants (Stone et al. 2007). Stone and his colleagues (2007) concluded that if recruiters come from countries with collectivistic values, in that case it is more likely that the priority will be given to the personal or relationship-oriented recruitment sources, such as employee referrals, networking at job fairs etc. In contrast, when recruiters belong to countries where individualistic values are dominated aforementioned authors believe that the recruiters in this case will opt for recruitment sources such as employment agencies, newspapers advertisements, online recruiting, or sources where personal acquaintance and personal contacts are not of great importance (Stone et al., 2007).

It is also believed that the system of values of the applicants can influence the process of recruitment by deciding for which job to apply. If the applicants support the individualistic values there is an assumption that they would prefer jobs and organisations where they will be able to express their personal achievements and quality, or jobs that offers a significant degree of autonomy 
and opportunity for advancement. On the other hand, if the applicants have collectivistic values, Stone and his colleagues (2007) state that it is more likely that such applicants will apply for jobs that will allow them to work in a team, and to cooperate with others.

Rieche and colleagues (2012) also state that national culture exerts some influence on the process of recruitment. They state that in collectivist cultures organisations prefer firstly to look for individuals for the vacant position within the organisation (internal recruitment) in order to encourage loyalty and commitment of the existing employees (Rieche et al., 2012). In support of the preference for internal recruitment in such cultures, some other authors also state that if some applicants come from the external labour market later they have difficulties to fit into the work environment and develop social relations with other employees, and even face with some kind of resistance (Björkman \& $\mathrm{Lu}, 1999)$.

National culture, may also influence the process of selection of applicants in several ways: through the profile of the ideal applicant, selection criteria and methods of selection. So, for example, in the USA, whose culture is individualistic and characterised by individual orientation towards achievements, efficiency and rationality, organisations prefer job applicants who support individualistic values, who are focused on results, who are proactive and can autonomously perform tasks (Stone et al. 2007). On the other hand, if it is about collectivist culture, then the profile of the ideal job applicant is different - priority is given to the applicants who are willing to work in a team and who subordinate their own goals to the goals of group or organisation.

Regarding the impact of national culture on the selection process Aycan (2005) states that in cultures that are high performance oriented organisations in the selection process mostly use hard criteria, such as job related knowledge and technical skills, while the organisation which are low performance-oriented favor soft criteria, such as relational skills, or even belonging to a certain social class (Aycan, 2005).

The influence of national culture can be recognised when it comes to the usual methods of selection, too. For example, in cultures that are characterised by high risk avoidance, organisations use a wide range of methods in order to gather enough information upon which will be based valid decision. Also, in cultures that are highly performance-oriented the methods that are standardized and closely linked to the job requirements are used to a much greater extent.

The influence of national culture is also recognised when it comes to training and development of the employees. For example, in high power distance cultures where coaches have great authority, the communication between them and the trainees is very formalised. Furthermore, the influence of culture can be recognised when it comes to the design of the training 
programmes. In which direction can go this impact, it can be seen from the results of the study conducted on the population of students in the USA who come from different countries and cultures. Research has shown that the AngloAmericans (individualistic culture) prefer training programmes that are individualised and goal oriented (focused on the realization of precisely defined tasks and goals) and where the learning environment is competitive. On the other hand, when it comes to students who come from countries in Latin America (collectivist cultures), it was found that they prefer unstructured learning methods, informal environment during the training programmes, followed by training methods that group oriented, as well as training methods that allow active participation and experimentation (McIntyre, 1996 in Stone et al., 2007). Another study showed that students from Asia (collectivist culture) prefer formal training sessions, training methods that are group oriented, cooperative learning environment, etc. (Chi-Ching \& Noi, 2001 in Stone et al. 2007). From the above arises the message that in order to create effective training programmes, it is necessary to design them in accordance with the preferences of the trainees which are substantially based on cultural values of the country of origin.

Culture can also affect employees performance appraisal system. This influence can be identified at each stage of this process. Stone and his colleges (2007) indicate that the values endorsed by the members of particular national culture, first of all, affect the criteria which usually are used for measuring the performance of the employees, methods that are used to measure employees performance, as well as the methods that are used to provide employees with feedback (Stone et al., 2007). In explaining how cultural values influence the performance appraisal system these authors state that there are two types of criteria usually used in performance management systems: (a) task performance and (b) contextual performance criteria. These authors suggest that if it comes to the individualist culture that is more likely to be used task performance criteria. In this case, employees performance will be compared to the performance standards, tasks and responsibilities determined in job description. On the other hand, if it is about collectivist culture, then the contextual performance criteria will be more used, i.e., the successfulness of the employees will be appraised by how successful they are in cooperation, innovativeness, providing assistance to others, etc. (Stone et al., 2007). In short, when it comes to the individualist culture, the emphasis in evaluating performances is on the individual performances, while in collectivist emphasis is on teamwork and group results.

Dimensions of national culture have some influence on the appraisal system in terms of subject of the appraisal, too. For example, in high power distance cultures superiors require loyalty and obedience of his/her subordinates, so when it comes to assessing the performance of the employees performances that 
are evaluated are based on the behaviour of the employees, not on the results they achieved. Therefore, there is a belief that in such system, it is enough to monitor the work of the employees in terms if they meet the prescribed procedure to be evaluated positively.

Some dimensions of culture have an impact on the preferences when it comes to the methods that organisations use for appraisal purposes. Thus, certain studies suggest that the in individualist cultures it is more likely that a formal and individual appraisal system will use objective, while in collectivist cultures it is informal and subjective appraisal system (Stone-Romero \& Stone, 2002). Furthermore, some research suggests that when it comes to feedback interview, in individualist cultures, employees sometimes respond negatively, i.e. they express anger, and even a tendency toward a kind of revenge to the feedback agent in order to protect their integrity. On the other hand, in Japan (collectivist cultures) employees on the negative appraisal also react with emotions, but the dominant emotion is not anger, but shame because they did not achieve satisfactory performances (Stone-Romero \& Stone, 2002).

In other research it was found that the impact of culture can be recognised when it comes to the way of communication during the feedback interview, as well as what is the focus of the communication. It has been found that in individualist cultures appraisals are usually communicated by direct talking with employees, whereas in collectivist cultures feedback is usually given indirectly through some kind of friendly conversation (Hofstede, 1983). Regarding the content of the feedback, some studies have shown that in individualist cultures focus is on how employees to improve their performance in order to make progress in their career, whereas in collectivist cultures, this is not the case, since in them progresses in career is usually based on the years of employment (Milliman et al., 1998).

Culture, as a system of values and rules of behaviour may affect the compensation system, too. That impact goes so far that the word compensation that is used to indicate the rewards that employees receive in return for their work, has a different interpretation in different cultures. For example, in most European countries, this term is considered more as a repayment for injury or damages, so in this countries the term remuneration is more preferred (Vance \& Paik, 2006).

When it comes to compensation system the influence of national culture can be most apparently recognised in the area of designing the compensation package. Thus, in individualist cultures, it is commonplace that compensation depends on the performances of the individuals, while in collectivist cultures, this is usually not the case. In collectivist cultures, salary is usually fixed and if there is a variable part, it is usually based on the group or team performances. Further, the dimension of uncertainty avoidance also has its implications for the 
compensation system. Thus, in cultures with a high degree of uncertainty avoidance compensation packages are structured in a way that small part depends on performances, because this is a way to provided certainty and predictability in payments to employees. In contrast, in cultures with low risk avoidance compensation packages are generally structured so that greater share is variable and depends on the results that have been achieved (Chiang, 2005).

Culture dimension such as masculine vs. feminine values, has also its implications for the design of the compensation system. Thus, in cultures where dominate masculine values employees prefer rewards such as money, promotion and etc., while in the cultures where dominate feminine values, there are preferences towards intangible rewards (e.g. job security, recognition, etc.).

Knowing the impact of certain dimensions of national culture on the preferred content of HRM in a particular country is very important for MNCs when designing their system of IHRM. If MNC implements management system which is not in the line with generally accepted values and rules of behaviour in a specific country, employees in that entity of MNC dissatisfaction with such system can expressed through low level of commitment and motivation as well as through unsatisfactory performances. Therefore, it is necessary that MNC creates such system of IHRM that at least will be a balance between the policies and procedures advocated by headquarters and those that are preferred in entities abroad.

\section{Impact of Dimensions of National Culture on the Content of Human Resource Management in Some Countries - Cases of Japan, USA, Turkey and Serbia}

Having in mind that dimensions of national culture have some influence on the preferred content of the HRM system in organisations of the certain country, hereinafter will be analysed examples of Japan, the USA, Turkey and Serbia. More precisely, the author will analyse how dimensions of national culture of these countries affect the HRM system in their organisations.

Japan. One of the main characteristic of the national culture of Japan is collectivism. How collectivism is strong, or how individualism is weak, it can be concluded upon the results that Hofstede obtained. This author found that the index of individualism of Japanese culture is 46 , while, by comparison, in the US, this index has value 91 (Hofstede, 1997). Strong collectivistic orientation in Japan can also be seen on the basis how people in this country understand the basic group to which they belong. Namely, in Japan, as a member of one`s basic group (which typically include spouses and children) is also consider organisation in which one works (Tayeb, 2004). 
In addition, national culture of Japan is not only characterised by collectivism, it is also characterised by masculine values, pursuit for achievements, willingness to hard work and sacrifice. In addition, the national culture of this country is characterised by high uncertainty avoidance, too. This is one of the reasons why most organisations in this country, despite all the turbulence in the labour market, still offer lifelong employment in exchange for loyalty and adequate performances. Among the other characteristics of national culture of Japan that should be mentioned is the orientation towards harmony. It reflects the orientation of avoiding conflicts, achieving harmony and establishing cooperative relations. In addition, the culture of Japan is also characterised by very strong respect for social status. This dimension of culture in everyday life manifests itself in numerous ways, such as, for example, the depth of the slope during the meeting, the way in which seating at the table is organised, the time that individuals are allowed to speak in the group, etc.

Main characteristics of the HRM system in organisations in Japan which are culturally grounded are as follows (Tayeb, 2004):

- Teamwork: multi-skill work teams, team appraisal and reward.

- Collective decision-making.

- Discreet performance appraisal.

- Life-time (long-term) employment for regular core employees.

- Seniority-based pay and promotion.

- Strong sense of obligation to colleagues and superiors, however to a certain extent discrimination against women.

- Commitment to high quality.

- Loyalty and long-term commitment to organisation, etc.

United States of America. Hofstede (1997) in his research found that one of the main characteristics of the national culture of the United States of America (USA) is individualism. This dimension of national culture of USA manifests itself in many ways. For example, members of this culture believe that every individual shapes and controls his/her own destiny. In addition, people are very ambitious, independent and put high value on freedom and individual achievements. In addition to individualism, the national culture of the USA is characterised by a low power distance (index 40). This dimension of culture manifests by advocating egalitarianism - attitudes towards people are not based on differences in status, age and the like. Furthermore, the USA national culture characterizes supporting masculine values (index 62). This dimension of culture manifests itself in a way that there is a strong tendency for achievements. An important characteristic of USA culture is also high tolerance of uncertainty (index 46) (Hofstede, 1997). This characteristic means that people in this country generally support changes and are motivated for entrepreneurship behaviour. 
The other characteristics of the national culture of USA include ethnocentrism and orientation towards future. Ethnocentrism manifests in a way that there is a strong belief that their system of values is superior than the others (Tayeb, 2004). As a result of orientation towards future in the USA generally dominates attitude that current ways of operation and functioning can and should always be replaced by better ones.

The implications of these dimensions of national culture of USA on the dominant characteristics of HRM system in this country, manifest in the following way (Tayeb, 2004):

- Promotion and reward are based on merits not on the status, age and the like.

- Preference towards participative leadership style.

- Employees are willing to make decisions, take initiative, build their image and demonstrate entrepreneurial behaviour.

- Subordinates have freedom to question authority of the superiors.

- Employees are willing to leave the organisation in order to build their careers and achieve greater success.

- Organisations easily decide to lay off employees.

- Problems with employees prefer to be solved through HRM system that is seen as a means to avoid the need for union organizing.

- A high degree of professionalism, etc.

Turkey. Basic dimensions of national culture of Turkey are collectivism, high degree of uncertainty avoidance, high power distance, equal level of masculine and feminine values (Hofstede, 1997). Also this is a highly contextual culture (Tayeb, 2004). However, studies conducted recently show that certain dimensions of Turkish national culture, such as collectivism have a high degree of uncertainty avoidance and high degree of power distance are somewhat relativised (Ayacan, 2001). Having in mind the geographical position of Turkey this tendency is not surprising.

Dimensions of national culture of Turkey have the influence on HRM practices in this country in the following ways:

- There is a large power distance between superiors and subordinates, although some managers express a high degree of tolerance, and empathy.

- Autocratic leadership style is increasingly relativised.

- Managers are high achievement-oriented but low power-oriented,

- There is still inequality in the decision-making process.

Serbia. Basic dimensions of Serbian national culture are collectivism, high power distance, uncertainty avoidance and the balance between masculine and feminine values (Hofstede, 2002). An important dimension of Serbian culture is, above all, collectivism. How collectivism is strong or how individualism is 
low may be concluded according to the value of the index of individualism (25). Furthermore, Serbia is a very strong power distance culture which indicates the value of this index, too. According to the research conducted by Hofstede this index is 86. However, dominant dimension of national culture in Serbia is uncertainty avoidance since this index has value 92. When it comes to masculine and feminine values, in Serbia they are almost equally represented. Index of masculine values is 43 (Hofstede, 2002).

In the absence of the empirical studies in which correlation between certain dimensions of national culture of Serbia and the content of HRM system that is applied in the organisations in this country, can be identified, certain theoretical studies, however, suggest that the above-mentioned dimensions of national culture of Serbia affect that the most common procedure and practice in the field of HRM in Serbian organisations to be as follows (Bogićević Milikić, 2009):

- Due to high uncertainty aversion, in filling the senior managerial positions, the priority is given to internal recruitment, while when it comes to filling junior management positions the advantage has the external recruitment. In the case when mid-level managers recruit from external sources, due to high risk aversion organisations usually seek the assistance of consultants.

- High degree of collectivism affects that preferred methods of recruitment are recommendations of existing staff, various events (seminars, symposia, etc.), job fairs, etc., rather than recruitment by newspapers adds or by erecruitment.

- Due to a high degree of collectivism and risk avoidance the organizations in Serbia when advertising the need for filling the vacant positions stress that job involves teamwork, interaction with others, security and so on, rather than possibilities of individual achievements (although this situation is changing in favor of individual achievements - B. Dj.).

- When it comes to the selection process, high power distance, high degree of collectivism and feminine values are not often standardised, and are based on the recommendations of someone who is already a member of the organization, unstructured interviews and informal conversation with the candidate. In these circumstances, the most common selection criteria are: personality traits (the impact of feminine values), education (the impact of high power distance), loyalty and harmony in the organization (the impact of collectivism).

- When it comes to the promotion, high degree of collectivism and high power distance imply that it is realistic to expect that in Serbian organizations basic criteria for advancement are good interpersonal relations, years of service, loyalty and commitment to the organization.

Finally, high degree of collectivism and high risk aversion lead to the conclusion that preferred reward system in Serbian organization is one where 
salary is fixed, i.e. independent of the achieved performances, or at least that its major part has fixed character.

\section{Conclusion}

Having in mind the fact that business expansion beyond the borders of a country becomes precondition for the organizations` further progress, but also for the development of the national economy as a whole, as well as that the number of organizations that operate at the international business scene increase, this paper deals with one of the biggest challenges of the process of internationalisation of business. That is the creation of adequate human resources management system. This is a challenge because employees who are employed in the entities abroad usually have different cultural background. This paper points out that although the content of the IHRM system is caused by a variety of factors from the international context, the national culture is of a particular importance since this factor has impact on a deeply based way of thinking, attitudes and behaviour of people. As a result, it is natural to expect that employees from different countries exhibit different preferences for policies and procedures in this area. While some HRM practices may consider adequate and appropriate, others may be considered inappropriate or even the unnatural. Since the employees dissatisfaction with IHRM system can be expressed through low level of organizational commitment and low level of performances, organizations when design HRM system that is going to be implemented in the entities abroad, this system, at the very least, should be a compromise between the system of values and standards of behaviour for which headquarter of the organization is stands for, with a system of values and norms of behaviour that local population prefer.

To highlight a clear link between certain dimensions of national culture and preferred policies and procedures in the field of human resources management, this paper firstly pointed out the essence of the concept of IHRM as well as its main segments. It was noted that the basis of all segments of IHRM is culture. It was also noted that culture is the factor upon which in the case of the internationalisation of business should be paid special attention. Further, the dimensions of national culture are observed from the perspective of the referent authors in this field are presented. Their effects on the policies and procedures in the field of HRM are also analysed. In the last part of the paper four countries were selected and key dimensions of their national cultures were analysed, as well as how these dimensions influence the content of HRM in these countries.

Although this paper has its limitations, which is primarily reflected in the lack of the empirical research that will confirm the causal relationship between the dimensions of particular national culture and policies and procedures in the field HRM that are appropriate for organisations of that country, it can serve as a kind of guidance for the management who plans to internationalize the 
business which factors should be taken into account in order to create an effective IHRM system.

\section{References}

Aycan, Z. (2001). Human resource management in Turkey - Current issues and future challenges. International Journal of Manpower, 22 (3), 252-260.

Aycan, Z. (2005). The interplay between cultural and institutional/structural contingencies in human resource management practices. International Journal of Human Resource Management, 16 (7), 1083-1119.

Björkman, I. \& Lu, Y. (1999). The management of human resources in Chinese-Western joint ventures, Journal of World Business, 34 (3), 306-325.

Bogićević, Milikić, B. (2009). The influence of culture on human resource management processes and practices: the propositions for Serbia. Economic Annals, 54 (181), 93118.

Brewster, Ch., Sparrow, P. \& Vernon, G. (2007). International Human Resource Management. London: Chartered Institute of Personnel and Development, CIPD House.

Briscoe, R. D., Schuler, S. \& Claus, L. (2009). International human resource management: policy and practice for multinational enterprises. Abingdon: Routledge.

Chiang, F. (2005). A critical examination of Hofstede's thesis and its application to international reward management. International Journal of Human Resource Management, 16 (9), 1545-1563.

Chi-Ching, Y., \& Noi, L. S. (2001). Learning styles and their implications for cross-cultural management in Singapore. Journal of Social Psychology, 134 (5), 593-600. (Quoted in Stone, D. L., Stone-Romero, F. E. \& Lukaszewski, M. K. (2007). The impact of cultural values on the acceptance and effectiveness of human resource management policies and practices, Human Resource Management Review, 17 (2), 152-165.).

Gomes, Sh. (2012). International Human Resource Management, Retrieved from: http://xisspm.files.wordpress.com/2012/02/chap-2-concept-of-ihrm.pdf., Accessed 6. July 2015.

Đorđević, B., Ivanović-Đukić, M. (2013). Challenges of the International Business Communication and Implication for Human Resource Management Function. Economic Themes,51 (2), 273-292.

Hills, M. D. (2002). Kluckhohn and Strodtbeck's Values Orientation Theory. Online Readings in Psychology and Culture, 4 (4), Retrieved from: http://dx.doi.org/10.9707/2307-0919.1040, Accessed 6. July 2015.

Hofstede, G. (1980). International Differences in Work-Related Values. Beverly Hills: Sage Publication.

Hofstede, G. (1983). The cultural relativity of organizational practices and theories. Journal of International Business Studies, 14 (2), 75-89.

Hofstede, G. \& Bond, M. H. (1984). Hofstede's Culture Dimensions: An Independent Validation Using Rokeach's Value Survey. Journal of Cross-Cultural Psychology, 15 (4), 417-433.

Hofstede, G. (1997). Cultures and Organizations. Software of the Mind, New York: McGraw Hill.

Hofstede, G. (2001). Culture`s Consequences. Thousand Oaks, CA: Sage Publications.

Hofstede, G. (2002). Images of Europe: past, present and future. U: Warner M. \& P. Joynt (Eds), Managing Across Cultures (pp. 89-103). London: Thompson. 
House R. J., Hanges, P. J., Javidan, M., Dorfman, P. W. \& Gupta, V. (2004). Culture, Leadership, and Organizations. The GLOBE Study of 62 Societies. Thousand Oaks, CA: Sage.

Janićijević, N. (2013). Organizaciona kultura i menadžment. Beograd: Centar za izdavačku delatnost Ekonomskog fakulteta u Beogradu.

Kluckhohn, F. R. \& Strodtbeck, F. L. (1961). Variations in value orientations. Evanston, IL: Row, Peterson. (Quoted in Hills, M. D. (2002). Kluckhohn and Strodtbeck's Values Orientation Theory. Online Readings in Psychology and Culture, 4 (4), Retrieved from: http://dx.doi.org/10.9707/2307-0919.1040, Accessed 6. July 2015.).

Leung, K. R., Bhagat, S., Buchan, N. R, Erez, M.\& Gibson, C. B. (2005). Culture and international business: recent advances and their implications for future research. Journal of International Business Studies, 36 (4), 357-378.

McIntyre, T. (1996). Does the way we teach create behavior disorders in culturally different students? Education and Treatment of Children, 19 (3), 354-370. (Quoted in Stone, D. L., Stone-Romero, F. E. \& Lukaszewski, M. K. (2007). The impact of cultural values on the acceptance and effectiveness of human resource management policies and practices, Human Resource Management Review, 17 (2), 152-165).

Milliman, J., Nason, S., Gallagher, E., Huo, P., Von Glinow, M. A \& Lowe, K. B. (1998). The impact of national culture on human resource management practices: The case of performance appraisal. In: Cheng, J. L. \& Peterson R. B. (Eds.), Advances in International Comparative Management (pp. 157-183). Greenwich: JAI Press.

Ralston, D. A., Holt, D. H., Terpstra, R. H. \& Yu, K.-C. (1997). The Impact of National Culture and Economic Ideology on Managerial Work Values: A Study of the United States, Russia, Japan, and China. Journal of International Business Studies, 28 (1), 177-207.

Reiche, S. B., Lee, Y. T. \& Quintanilla, J. (2012). Cultural perspectives on comparative HRM. In: Brewster, C. \& Mayrhofer, W. (Eds.), Handbook of Research in Comparative Human Resource Management (pp. 51-68). Cheltenham: Edward Elgar.

Scullion, H. (2005). International HRM: an introduction. In: Scullion, H. \& Lineham, M. (Eds.), International Human Resource Management. A critical text (pp. 3-10). London/NY: Palgrave Macmillan.

Stone, D. L., Stone-Romero, F. E. \& Lukaszewski, M. K. (2007). The impact of cultural values on the acceptance and effectiveness of human resource management policies and practices, Human Resource Management Review, 17 (2), 152-165.

Stone-Romero, E. F. \& Stone, D. L. (2002). Cross-cultural differences in response to feedback: Implications for individual, group, and organizational effectiveness. In: Ferris, G. R. (Ed.), Research in personnel and human resource management (pp. 275-372). Greenwich: JAI Press.

Tayeb, M. (2004). International Human Resource Management: A Multinational Company Perspective. Oxford: Oxford University Press.

Taylor, S., Beechler, Sch. \& Napier, N. (1996). Toward an integrative model of strategic international human resource management. The Academy of Engagement Review, 21 (4), 959-985.

Thomas, C. D. (2008). Cross-cultural management: Essentials concepts (2nd ed). Thousand Oaks: SAGE Publishing.

Triandis, H. C. (1995). Individualism and collectivism. Boulder: Westview.

Trompenaars, F. \& Hampden-Turner, C. (1997). Riding the Waves of Culture: Understanding Cultural Diversity in Business (2nd ed). London: Nicholas Brealey Publishing. (Quoted in Vance, M. Ch. \& Paik, Y. (2006). Managing a global 
workforce: challenges and opportunities in international human resource management. New York: M.E: Sharpe, Inc.).

Vance, M. Ch. \& Paik, Y. (2006). Managing a global workforce: challenges and opportunities in international human resource management. New York: M.E: Sharpe, Inc.

\section{UTICAJ NACIONALNE KULTURE NA MEĐUNARODNI MENADŽMENT LJUDSKIH RESURSA}

Apstrakt:U današnjim uslovima poslovanja internacionalizacija poslovnih aktivnosti postaje gotovo nezaobilazan uslov za dalji rast i razvoj preduzeća. Međutim, izlazak na međunarodnu poslovnu scenu najčešce zahteva da organizacije izvrše određene promene u načinu na koji su do tada funkcionisale. Jedna od oblasti koja zahteva izvesne promene jeste i oblast upravljanja ljudskim resursima. Faktori koji uslovljavaju modifikacije u ovom sistemu vezani su, pre svega, za pravnu regulativu drugih zemalja, ali i za karakteristike nacionalne kulture. Ovo zbog toga što nacionalna kultura ispoljava snažan uticaj na sistem vrednosti, stavove i ponašanje ljudi $u$ određenoj zemlji pa, između ostalog, i na preferencije prema politikama i procedurama iz oblasti menadžmenta ljudskih resursa. Polazeći od navedenog, rad se bavi analizom uticaja pojedinih dimenzija nacionalne kulture na preferirani sadržaj menadžmenta ljudskih resursa u organizacijama u određenim zemljama. Cilj rada je da se pruži teorijska osnova koja će omogućiti organizacijama koje su internacionalizovale poslovanje, ili to nameravaju da učine, da kreiraju takav sistem menadžmenta ljudskih resursa $\mathrm{u}$ entitetima $\mathrm{u}$ inostranstvu koji bi, u najmanju ruku, predstavljao balans između sistema koji se primenjuje $u$ sedištu organizacije i onog koji se preferira u entitetima $u$ inostranstvu da bi ovaj sistem bio efektivan.

Ključne reči: internacionalizacija poslovanja, nacionalna kultura, međunarodni menadžment ljudskih resursa, zaposleni.

\section{Author's biography}

Biljana Đorđević graduated from the Faculty of Economics in Niš 1992. She recieved her M Sc (1998) and PhD (2007) at the Faculty of Economics in Belgrade. She is an Associate Professor at the Faculty of Economics in Niš, teaching the the following subjects Managing the Enterprises` Resources, Human Resource Management, International Human Resource Management and Career Management. She has published more than eighty scientific and professional papers, university textbook Human Resource Management (co-author) and monograph Career Success. Her fields of interest include human resource management, career management and managing the enterprises` resources. 